\title{
Biotransformation of anthracene and fluoranthene by Absidia fusca Linnemann
}

\author{
Danièle Villemain \\ Laboratoire Radiopharmaceutiques Biocliniques \\ INSERM 0340, UFR de Médecine de Grenoble \\ Université Joseph Fourier \\ 38706 La Tronche cedex, France \\ Tel: 33476637100 \\ E-mail: daniele.villemain@ujf-grenoble.fr \\ Pascale Guiraud* \\ Laboratoire Oligoéléments et Résistance au Stress Oxydant induit par les Xénobiotiques \\ ORSOX, EA3776 - CEA LRC 8M, UFR de Pharmacie de Grenoble \\ Université Joseph Fourier \\ 38706 La Tronche cedex, France \\ Tel: 33476637515 \\ Fax: 33476637423 \\ E-mail: pascale.guiraud@ujf-grenoble.fr \\ Ouahiba Bordjiba \\ Institut des Sciences de la Nature \\ Université d'Annaba \\ 23000 Annaba, Algeria \\ Tel: 21338875400 \\ Fax: 21338875400 \\ E-mail: ouahiba_bordjiba@yahoo.fr

\section{Régine Steiman} \\ Laboratoire Oligoéléments et Résistance au Stress Oxydant induit par les Xénobiotiques \\ ORSOX, EA3776 - CEA LRC 8M, UFR de Pharmacie de Grenoble \\ Université Joseph Fourier \\ 38706 La Tronche cedex, France \\ Tel: 33476637515 \\ Fax: 33476637423 \\ E-mail: regine.steiman@ujf-grenoble.fr
}

Keywords: Absidia fusca, anthracene, biodegradation, fluoranthene, kinetics.

Abbreviations: AC: anthracene

$\mathrm{CV}$ : coefficient of variation

FA: fluoranthene

GS: Galzy Slonimski (liquid medium)

HPLC: High Performance Liquid Chromatography

MEA: malt extract agar

PAHs: polycyclic aromatic hydrocarbons

PLSD: Protected Least Significant Difference

S: strain

T: temperature

t: time

A strain of Absidia fusca was isolated from a pesticidecontaminated soil (Annaba, Algeria). The biotransformation capability of this strain towards two polycyclic aromatic hydrocarbons (PAHs): anthracene and fluoranthene was compared to that exhibited by another strain of $A$. fusca isolated from a noncontaminated milieu and considered as a control. The results obtained were statistically analyzed and showed that the strain isolated from the contaminated soil was more efficient than the control to remove anthracene from the medium, during all the kinetics $(90 \%$ removed versus $45 \%$ after $24 \mathrm{hrs})$. Concerning fluoranthene, the amount removed by both strains was very high during the first $\mathbf{2 4}$ hrs however the control strain was slightly more efficient $(94 \%$ versus $89 \%)$ while the results were similar for the two strains during the rest of the kinetics. This study reveals for the first time the potential interest of the species $A$. fusca for the bioremediation of PAHs.

*Corresponding author 
Table 1. Multifactorial analysis of variance corresponding to the amount of transformed anthracene.

\begin{tabular}{|c|c|c|c|c|c|}
\hline Source of variation & $\mathrm{dF}^{\mathrm{b}}$ & $\mathbf{S S}^{\mathrm{c}}$ & $\mathbf{M S}^{d}$ & $\mathbf{F}$ & $\mathbf{p}$ \\
\hline S Factor & 1 & 38.34 & 38.34 & 172.03 & $<0.0001$ \\
\hline T Factor & 1 & 1.47 & 1.47 & 6.60 & 0.012 \\
\hline t Facteur & 4 & 48.16 & 12.04 & 54.02 & $<0.0001$ \\
\hline$S^{*} T^{a}$ & 1 & 2.51 & 2.51 & 11.26 & 0.001 \\
\hline $\mathrm{S}^{*} \mathrm{t}^{\mathrm{a}}$ & 4 & 0.82 & 0.20 & 0.92 & 0.46 \\
\hline $\mathrm{T}^{*} \mathrm{t}^{\mathrm{a}}$ & 4 & 1.99 & 0.50 & 2.23 & 0.072 \\
\hline$S^{*} T^{*} t^{a}$ & 4 & 1.00 & 0.25 & 1.13 & 0.35 \\
\hline Residual & 100 & 22.29 & 0.22 & & \\
\hline
\end{tabular}

Polycyclic aromatic hydrocarbons (PAHs) are fused ring aromatic compounds formed during the incomplete combustion of almost any organic material and are ubiquitously distributed in the environment (Menzie et al. 1992; Cerniglia, 1993; Chaudhry, 1994). Some of them are considered as dangerous substances because of their toxic and mutagenic or carcinogenic potentialities (Menzie et al. 1992; Nadon et al. 1995), and 16 are present on the list of priority pollutants established by the US Environmental Protection Agency (EPA). The presence of PAHs in contaminated soils and sediments poses a significant risk to the environment and human health. PAHs are hydrophobic compounds, whose persistence within ecosystems is due chiefly to their low aqueous solubility (Chaudhry, 1994). Fluoranthene is the most abundant PAH in the environment, and is so considered as a pollution indicator (Chaudhry, 1994). Anthracene is another model compound for PAHs degradation studies: its structure is found in carcinogenic PAHs such as benzo (a) pyrene and benzo (a) anthracene (Müncnerova and Augustin, 1994).

Microbial biotransformation is a major environmental process affecting the fate of PAHs in both terrestrial and aquatic ecosystem (Mahmood and Rama Rao, 1993; Kästner and Mahro, 1996). A large number of bacteria that metabolize PAHs have been isolated (Alcaligenes denitrificans, Rhodococcus sp, Pseudomonas sp, Mycobacterium sp.) (Cerniglia, 1993; Harayama, 1997; Dean-Ross et al. 2001; Moody et al. 2001). A variety of bacteria can degrade certain PAHs completely to $\mathrm{CO}_{2}$ and metabolic intermediates (Kelley et al. 1993; Müncnerova and Augustin, 1994). Knowledge on fungal degradation is more limited: PAHs are oxidized to phenolic metabolites by co-metabolic process (Cerniglia, 1993; Paszczynski and Crawford, 1995; Cerniglia, 1997; Harayama, 1997). Non specific oxidation reaction catalyzed, by extracellular enzymes of white rot fungi, lead to the formation of a variety of quinones and hydroxylated aromatic compounds (Hammel, 1995; Bogan and Lamar, 1996, Tekere et al. 2005). A detailed investigation on fungal metabolism of fluoranthene was realized in Cunnighamella elegans (Müncnerova and Augustin, 1994). Preliminary works have been done in our team to evaluate the degradation or transformation of anthracene, fluoranthene, and pyrene by selected soil fungi (Krivobok et al. 1998; Salicis et al. 1999; Ravelet et al. 2000). Further studies have been recently conducted to evaluate the potential induction of the biodegradation capabilities towards anthracene and fluoranthene in fungi isolated from a contaminatedmilieu (Giraud et al. 2001). In addition, we have recently shown that anthracene can be toxic to some soil fungi (Bonnet et al. 2005). The genus Absidia is not known as efficient in the bioremediation of environmental pollutants. To our knowledge, there has been no report on the metabolism of xenobiotics by Absidia fusca Linnemann, except our recent reports about herbicides (Bordjiba et al. 2001) and phenolic compounds (Guiraud et al. 2003).

In this study, the purpose was to investigate the ability of Absidia fusca to degrade these two compounds. Two strains were compared: one from the CBS-Baarn collection (normal forest soil), the other isolated from a polluted soil, and the results of the degradation kinetics obtained were statistically analyzed.

\section{MATERIALS AND METHODS}




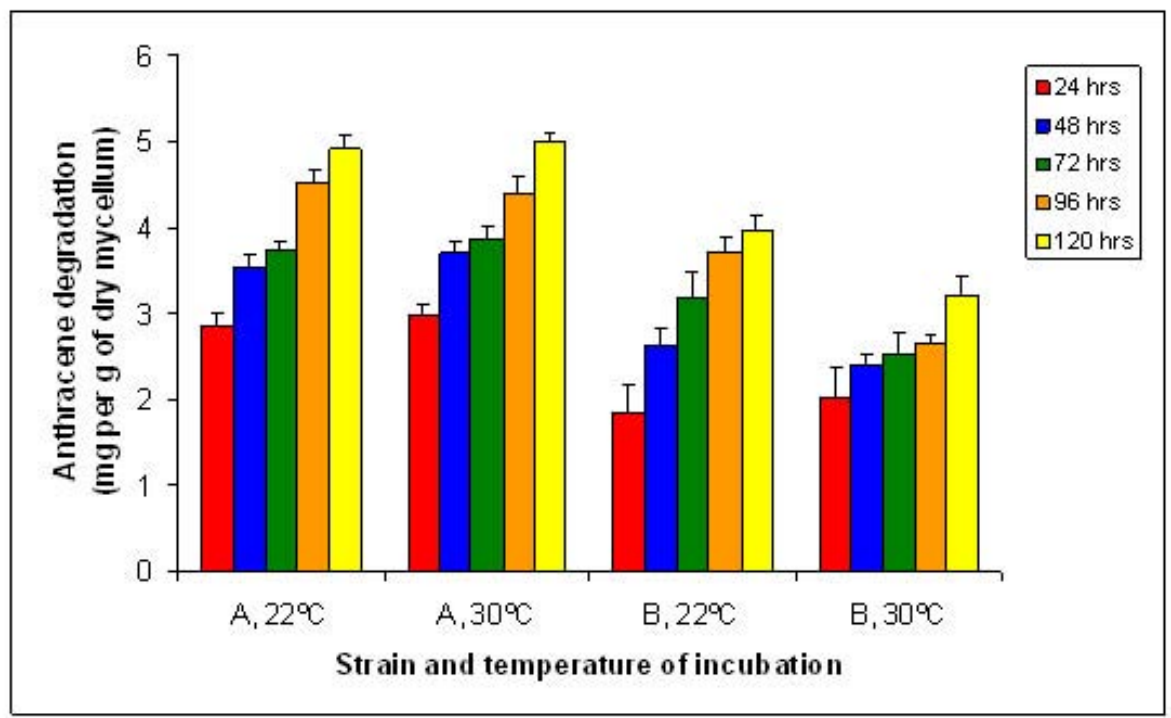

Figure 1. Strain*Temperature*time interaction for anthracene transformation by $A$. fusca strains A and B (error bars: one standard error).

\section{Chemicals}

Anthracene (AC) and fluoranthene (FA) were purchased from Sigma-Aldrich (Sigma Chemical Co., St Louis, MO, USA). Agar and malt extract were respectively from Coopérative Pharmaceutique Française (Melun, France) and Difal (Villefranche-sur-Saône, France). Other products were from Prolabo (Paris, France).

\section{Media and culture conditions}

The solid medium used for maintaining the cultures contained: malt extract $15 \mathrm{~g} \mathrm{l}^{-1}$ - agar $15 \mathrm{~g} \mathrm{l}^{-1}$ (MEA). Galzy and Slonimski (1957) liquid synthetic medium (GS) was slightly modified by adding glucose at a final concentration of $5 \mathrm{~g}^{-1}$. The media were sterilized by autoclaving ( $20 \mathrm{~min}$, $121^{\circ} \mathrm{C}$ ) before use. The strains were reactivated on MEA medium for 8 days, before each experiment.

\section{Fungal strain isolation}

Absidia fusca Linemann (A) was isolated in our laboratory from a polluted soil from Algeria (Bordjiba et al. 2001) while A. fusca Linnemann (B) (CBS 102.35, Baarn, Hollande) was from soil from pine forest (Germany). The contaminated soil from Algeria came from a parcel treated by herbicides and fungicides (among which the herbicides: metribuzin, metobromuron, linuron, and metamitron, associated to the fungicides: propineb, maneozeb, and sandofan) where tomato and potato were cultivated (El Krous, $30 \mathrm{~km}$ east from Annaba). Soil samples were taken from 1 to $10 \mathrm{~cm}$ depth, collected in sterile tubes and stored at $+4^{\circ} \mathrm{C}$ until analyses. A. fusca (A) was isolated at $22^{\circ} \mathrm{C}$ and was stored at $4^{\circ} \mathrm{C}$ in slant tubes on MEA medium.

\section{Biotransformation assays}

To obtain sufficient inoculum for liquid medium cultures, the strains were grown for 1-2 weeks on MEA medium at $22^{\circ} \mathrm{C}$, without any adaptation to the xenobiotics. They were aseptically inoculated (mycelium and spores) into sterile GS liquid medium at $\mathrm{pH} 4.5$, containing glucose $\left(5 \mathrm{~g} \mathrm{l}^{-1}\right)$, and previously sterilized by autoclaving for $20 \mathrm{~min}$ at $121^{\circ} \mathrm{C}$. The $125 \mathrm{ml}$ Erlenmeyer flasks containing $35 \mathrm{ml}$ of inoculated medium were incubated at $22^{\circ} \mathrm{C}$ and $30^{\circ} \mathrm{C}$ under shaking (180 rpm, orbital shaker), for 2 days. At this stage, no glucose remained in the medium as determined with the glucose GOD-PAP assay kit (Roche Diagnostics, Meylan, France). Dimethylsulfoxide stock solutions of AC and FA were sterilized by filtration through $0.2 \mu \mathrm{m}$ Millipore membranes, and added at a final concentration of $0.01 \mathrm{~g} \mathrm{l}^{-1}$. The depletion of the compounds was evaluated after 5 days of cultivation at 22 and $30^{\circ} \mathrm{C}$. Light was 1200 lux with a photoperiod of $12 \mathrm{hrs}$ per day. Each series of experiments was run at least 3 times with assays in triplicate. For kinetics experiments, cultures were run at 22 or $30^{\circ} \mathrm{C}$ and stopped 24, 48, 72, 96 and $120 \mathrm{hrs}$ after the addition of the PAHs. Biotic controls consisted of fungal cultures to which the xenobiotic was added at the time of harvesting and processed immediately. Abiotic control consisted of cellfree flasks containing the xenobiotic. These controls, included in each series, served to correct the loss due to the binding to the mycelium or a physicochemical degradation.

\section{Analysis of PAHs}

Liquid media with mycelia, containing $\mathrm{AC}$ or $\mathrm{FA}$ were extracted with one volume of bidistilled ethyl acetate (25 $\mathrm{ml}$ ) by rotary shaking at $250 \mathrm{rpm}$ for $5 \mathrm{~min}$ and then at 180 $\mathrm{rpm}$ for $30 \mathrm{~min}$. Mycelia were filtered off and rinsed with ethyl acetate. The extraction was repeated twice. The organic phases were pooled, dried over anhydrous $\mathrm{Na}_{2} \mathrm{SO}_{4}$ 
Table 2. Multifactorial analysis of variance corresponding to the amount of transformed fluoranthene.

\begin{tabular}{|c|c|c|c|c|c|}
\hline Source of & $\mathbf{d F}^{\mathbf{b}}$ & $S^{c}$ & $\mathbf{M S}^{d}$ & $\mathbf{F}$ & $p$ \\
\hline S Factor & 1 & 0.900 & 0.900 & 12.16 & 0.0007 \\
\hline T Factor & 1 & 3.31 & 3.31 & 44.75 & $<0.0001$ \\
\hline t Facteur & 4 & 21.44 & 5.36 & 72.41 & $<0.0001$ \\
\hline$S^{*} T^{a}$ & 1 & 0.008 & 0.008 & 0.10 & 0.75 \\
\hline $\mathrm{S}^{*} \mathrm{t}^{\mathrm{a}}$ & 4 & 1.31 & 0.327 & 4.42 & 0.002 \\
\hline $\mathrm{T}^{*} \mathrm{t}^{\mathrm{a}}$ & 4 & 0.215 & 0.054 & 0.73 & 0.58 \\
\hline$S^{*} T^{*} t^{a}$ & 4 & 0.157 & 0.039 & 0.53 & 0.71 \\
\hline Residual & 140 & 10.36 & 0.074 & & \\
\hline
\end{tabular}

and evaporated to dryness at $40^{\circ} \mathrm{C}$ under reduced pressure. The residue was dissolved in acetonitrile $(1.5 \mathrm{ml})$ from which, after gently vortexing and filtration through a 0.2 $\mu \mathrm{m}$ membrane filter, an aliquot of $20 \mu \mathrm{l}$, was removed for HPLC analysis. HPLC was performed with a liquid chromatograph (Shimadzu) equipped with a LC 6A pump, an SIL-9A automatic injector and a RF-10AXL spectrofluorescence detector. The separation column, Supelcosil TM LC-PAH $5 \mu \mathrm{m}$, was $4.6 \mathrm{~mm}$ inside diameter x $150 \mathrm{~mm}$ (Supelco Inc., Bellefonte, PA). The mobile phase was acetonitrile: water $(70: 30, \mathrm{v}: \mathrm{v})$. The flow rate was $1 \mathrm{ml}$ min- 1 and detection was made at $280 \mathrm{~nm}$ ( $\lambda$ excitation) and $450 \mathrm{~nm}$ ( $\lambda$ emission) for FA and at $250 \mathrm{~nm}$ ( $\lambda$ excitation) and $450 \mathrm{~nm}(\lambda$ emission) for AC. The HPLC detection limit was $0.22 \mu \mathrm{g} .1^{-1}$ for FA and $0.49 \mu \mathrm{g} . l^{-1}$ for AC. Each sample was injected 3 times and the mean value was calculated.

\section{Evaluation of the level of xenobiotic transformed}

Residual amounts of AC and FA were calculated by the integrator connected to the HPLC system, with reference to a standard. The overall biotransformation efficiency (\%) was obtained after correction with regard to the abiotic degradation (not exceeding 5\%) and the extraction yield (ranging from 95 to $98 \%$ ). These values were then converted into $\mathrm{mg}$ of xenobiotic transformed per $\mathrm{g}$ of dry mycelium.

\section{Statistical analysis}

The treated data correspond to the amount of xenobiotic transformed expressed as $\mathrm{mg} / \mathrm{g}$ of dry mycelium. Reported results are means (M), standard errors of the means (SEM) andcoefficient of variation $(\mathrm{CV} \%)$.

For each xenobiotic a multifactorial analysis of variance was run, the factors being: strain S (two levels: A and B), temperature $\mathrm{T}$ (two levels: $22^{\circ} \mathrm{C}$ and $30^{\circ} \mathrm{C}$ ) and time $\mathrm{t}$ (qualitative factor, five levels: $24 \mathrm{hrs}, 48 \mathrm{hrs}, 72 \mathrm{hrs}, 96 \mathrm{hrs}$, $120 \mathrm{hrs}$ ). The homogeneity of the 20 variances was previously checked by the Cochran $\mathrm{C}$ test. The multifactorial analysis allowed to point out potential interactions between the 3 factors considered. The posteriori tests performed after analyses of variance were: Fisher PLSD test (Protected Least Significant Difference) which is the most powerful to detect differences, and Tukey-Kramer test which allows to assess the type I error probability. The conclusions of the second test are only mentioned if they are in contradiction with those of the Fisher PLSD. These studies were done using StatView version 5 (SAS Institute, Cary, NC).

Four groups were obtained when crossing the factors $\mathrm{S}$ and T: $\mathrm{A}, 22^{\circ} \mathrm{C} ; \mathrm{A}, 30^{\circ} \mathrm{C} ; \mathrm{B}, 22^{\circ} \mathrm{C} ; \mathrm{B}, 30^{\circ} \mathrm{C}$. Each of them was submitted to an analysis of variance of the time-dependent regression in order to test the significance and the linearity of the regression. The slopes of the linear regression curves were compared with the Student's $t$ test.

In all analyses the significance level $\alpha$ was 0.05 and $p$ values were considered significant at values below or equal to 0.05 .

\section{RESULTS}

\section{Kinetics of anthracene biotransformation by $A$. fusca}

The kinetics of $\mathrm{AC}$ transformation were run during five days for the four groups: $\mathrm{A}, 22^{\circ} \mathrm{C} ; \mathrm{B}, 22^{\circ} \mathrm{C} ; \mathrm{A}, 30^{\circ} \mathrm{C} ; \mathrm{B}$, $30^{\circ} \mathrm{C}$. Six replicates were done for each time. 


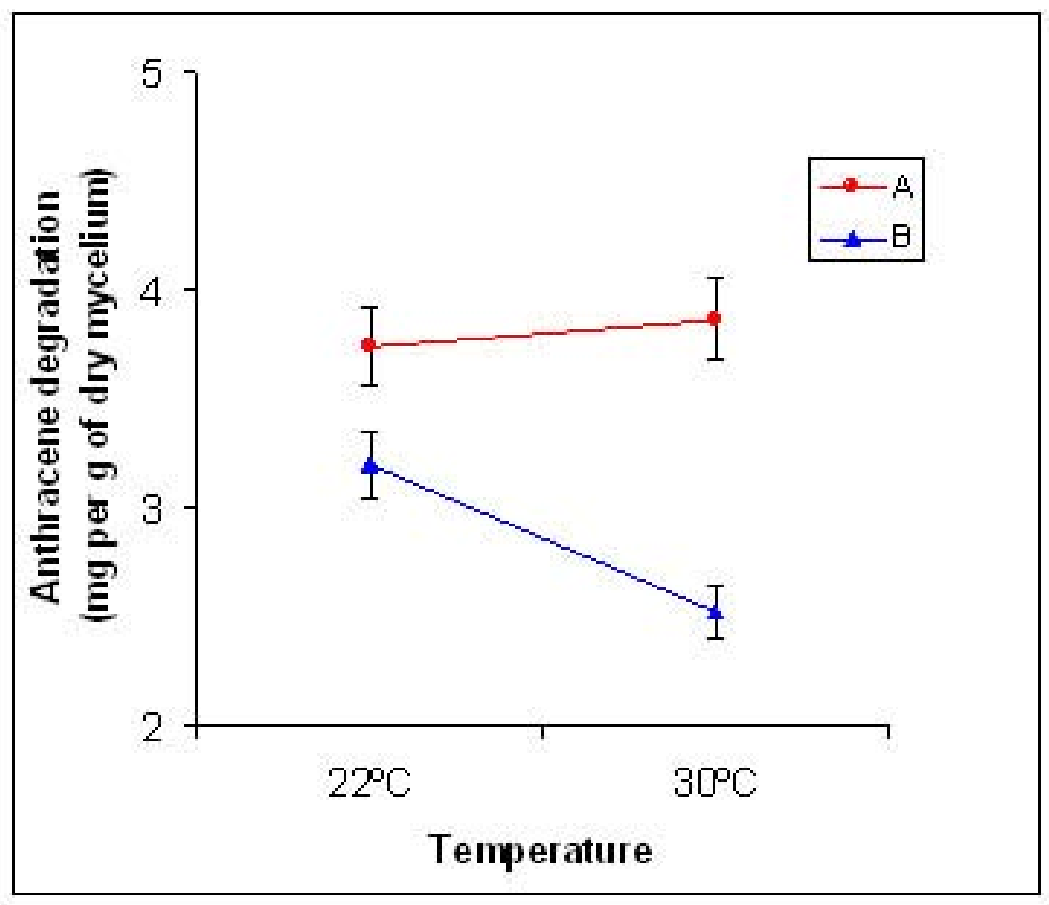

Figure 2. Strain*Temperature interaction for anthracene transformation by $A$. fusca strains $A$ and $B$ (error bars: one standard error; time: $72 \mathrm{hrs}$ ).

The chromatographic profiles revealed three peaks for both strains with retention times ranging from 0.5 and $2 \mathrm{~min}$ while the peak corresponding to $\mathrm{AC}$ was observed at 5 min in our experimental conditions (data not shown). The height and the area of the peaks increased during the first $24 \mathrm{hrs}$ and were higher for the strain A, while the peak corresponding to $\mathrm{AC}$ decreased at the same time. These peaks were not observed in the HPLC profiles of control extracts corresponding to the medium added by $\mathrm{AC}$ without fungus and the medium with fungus but without AC. All these observations strongly suggested that these three peaks corresponded to metabolites derived from AC. Moreover these peaks decreased after 24 hrs suggesting a biodegradation process.

The percentages of $\mathrm{AC}$ transformation were very high after $24 \mathrm{hrs}$ with the strain A: mean values were $89 \%(\mathrm{CV}=$ $10.6 \%)$ at $22^{\circ} \mathrm{C}$, and $88.1 \%(\mathrm{CV}=6.9 \%)$ at $30^{\circ} \mathrm{C}$. Concerning the strain $\mathrm{B}$, the values obtained were 2 times lower: $47 \%(\mathrm{CV}=17.2 \%)$ at $22^{\circ} \mathrm{C}$, and $41 \%(\mathrm{CV}=11.9 \%)$ at $30^{\circ} \mathrm{C}$. The corresponding results expressed in $\mathrm{mg} / \mathrm{g}$ of dry mycelium are given in Figure 1.

The coefficients of variation were high at $24 \mathrm{hrs}$ for all groups, and decreased after $24 \mathrm{hrs}$. They were mostly high for strain B during the first $72 \mathrm{hrs}$, reaching $40 \%$ at $24 \mathrm{hrs}$ (data not shown).

Results were then analyzed in order to determine the influence of the factors $\mathrm{S}$ and $\mathrm{T}$ on AC biotransformation. Table 1 gives the results of the multifactorial variance analysis. Figure 1 illustrates the $\mathrm{S}^{*} \mathrm{~T} * \mathrm{t}$ interaction (not significant, $\mathrm{p}=0.35$ ) and shows that strain $\mathrm{A}$ was more efficient than strain B for AC transformation, whatever the time and the temperature considered, this was confirmed by the demonstration of a significant strain effect $(p<0,0001)$. The factor $\mathrm{T}$ had no effect on strain $\mathrm{A}$, whatever the value of the factor $t$, although the temperature effect was significant $(p=0.012)$. The effect of the temperature depended on the strain since the $\mathrm{S} * \mathrm{~T}$ interaction was significant $(\mathrm{p}=0.001)$. This interaction reported in Figure 2 , showed that the mean amount of AC degraded by strain A was almost identical at $22^{\circ} \mathrm{C}$ and at $30^{\circ} \mathrm{C}(3.91 \mathrm{mg} / \mathrm{g}$ of dry mycelium versus $3.98 \mathrm{mg} / \mathrm{g}$ of dry mycelium, $\mathrm{p}=0.57$ ), while this mean amount was lower at $30^{\circ} \mathrm{C}$ than at $22^{\circ} \mathrm{C}$ $(2.56 \mathrm{mg} / \mathrm{g}$ of dry mycelium versus $3.07 \mathrm{mg} / \mathrm{g}$ of dry mycelium, $p<0,0001$ ) for strain B. More precisely, this difference with strain B was significant only after $72 \mathrm{hrs}(\mathrm{p}$ $=0.044), 96 \mathrm{hrs}(\mathrm{p}=0.002)$ and $120 \mathrm{hrs}(\mathrm{p}=0.03)$ with the Fisher PLSD test (only the difference obtained at $96 \mathrm{hrs}$ was significant with the Tukey-Kramer test, $p=0.05$ ). These results were confirmed by a $\mathrm{T}^{*} \mathrm{t}$ interaction closed to the significant value $(p=0.072)$, the graphic indicating an increase of the temperature effect during the kinetics (data not shown).

\section{Influence of the time of incubation on anthracene biotransformation}

The results of this multifactorial analysis showed the influence of the factors $\mathrm{S}$ and $\mathrm{T}$ on $\mathrm{AC}$ transformation. The results were separately studied for the four groups: $\mathrm{A}, 22^{\circ} \mathrm{C}$; $\mathrm{B}, 22^{\circ} \mathrm{C} ; \mathrm{A}, 30^{\circ} \mathrm{C} ; \mathrm{B}, 30^{\circ} \mathrm{C}$. 
An analysis of the regression variance showed for each group, a positive and significant regression of the amount of $\mathrm{AC}$ transformed according to the time of incubation $(\mathrm{p}<$ 0.0001 for the groups $\mathrm{A}, 22^{\circ} \mathrm{C} . \mathrm{B}, 22^{\circ} \mathrm{C} ; \mathrm{A} 30^{\circ} \mathrm{C}$ and $\mathrm{p}=$ 0.0008 for the group $\mathrm{B}, 30^{\circ} \mathrm{C}$ ).

The four kinetics are represented in Figure 3. The slopes (rate of AC transformation) were 0.0213, 0.0221, 0.0198 and $0.0111 \mathrm{mg} / \mathrm{g}$ of dry mycelium $/ \mathrm{h}$ respectively for the groups $\mathrm{A}, 22^{\circ} \mathrm{C} ; \mathrm{B}, 22^{\circ} \mathrm{C} ; \mathrm{A}, 30^{\circ} \mathrm{C} ; \mathrm{B}, 30^{\circ} \mathrm{C}$.

For the three first groups, these slopes were not statistically different $(\mathrm{p} \geq 0.54)$, and were around $0.50 \mathrm{mg} / \mathrm{g}$ of dry mycelium/d. For strain A from the contaminated sol, the kinetics run at $22^{\circ} \mathrm{C}$ and $30^{\circ} \mathrm{C}$ were similar (Figure 3). For strain $\mathrm{B}$ from the $\mathrm{CBS}$ collection, the kinetics run at $22^{\circ} \mathrm{C}$ was parallel to that observed with strain $\mathrm{A}$, but the amount of xenobiotic transformed was lower. However, the transformation was significantly faster at $22^{\circ} \mathrm{C}$ than at $30^{\circ} \mathrm{C}$ (difference between the slopes $=0.011 \mathrm{mg} / \mathrm{g}$ dry mycelium $/ \mathrm{h}, \mathrm{p}=0.003$ ), the rate of transformation was two times lower at $30^{\circ} \mathrm{C}$, around $0.26 \mathrm{mg} / \mathrm{g}$ of dry mycelium $/ \mathrm{d}$ (Figure 3). Altogether, these results confirmed for both strain $\mathrm{A}$ and $\mathrm{B}$, those obtained with the multifactorial variance analysis and with the "a posteriori" tests.

\section{Kinetics of fluoranthene biotransformation by $A$. fusca}

The kinetics of FA transformation were run as for AC. Eight replicates were done for each time.

The chromatographic profiles revealed four major peaks for both strains with retention times ranging from 0.9 and 2.1 min and two smaller peaks at 3.2 and 4 min while the peak

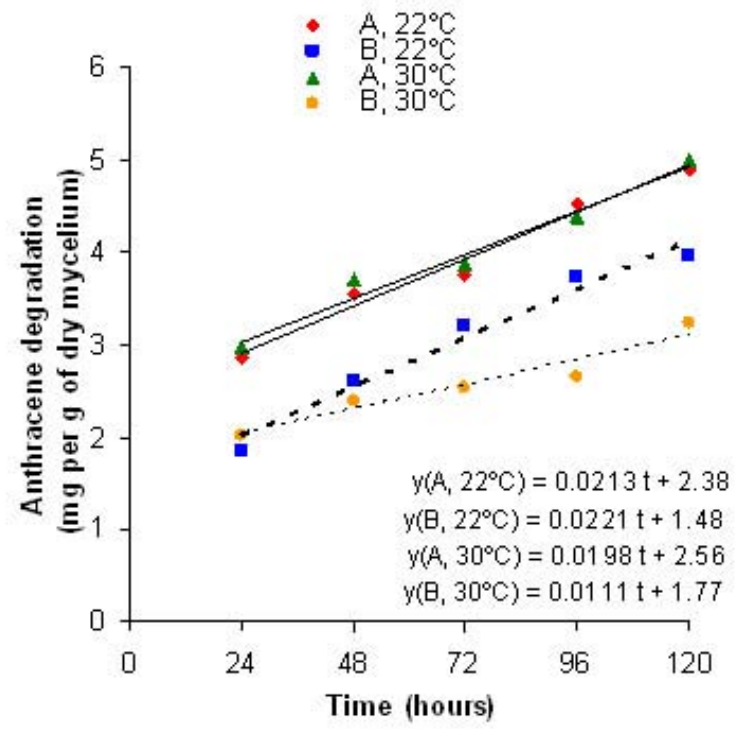

Figure 3. Kinetics of anthracene transformation by $A$. fusca strains $A$ and $B$ as a function of the temperature (mean values of the amount degraded). corresponding to FA was observed at $11 \mathrm{~min}$ in our experimental conditions (data not shown). The height and the surface of the peaks increased during the first $24 \mathrm{hrs}$, while the peak corresponding to FA decreased at the same time. These peaks were not observed in the HPLC profiles of control extracts corresponding to the medium added by FA without fungus and the medium with fungus but without FA. All these observations strongly suggested that these peaks corresponded to metabolites derived from FA. Moreover these peaks decreased after $24 \mathrm{hrs}$ suggesting a biodegradation process.

The percentages of FA transformation were very high after 24 hrs: mean values were $89.3 \%(\mathrm{CV}=4.3 \%)$ for the group $\mathrm{A}, 22^{\circ} \mathrm{C}, 87.3 \%(\mathrm{CV}=2.9 \%)$ for $\mathrm{A}, 30^{\circ} \mathrm{C}, 94.2 \%(\mathrm{CV}=$ $2.1 \%)$ for $\mathrm{B}, 22^{\circ} \mathrm{C}$ and $91.1 \%(\mathrm{CV}=3.6 \%)$ for $\mathrm{B}, 30^{\circ} \mathrm{C}$. Results expressed in $\mathrm{mg} / \mathrm{g}$ of dry mycelium, are given in Figure 4.

The coefficients of variation were all below $10 \%(\mathrm{~min}=$ $4.8 \%, \max =9.2 \%$ ). They were not very different according to the time in each group and also very similar from one group to another (mean values: $6.7 \%$ for $\mathrm{A}, 22^{\circ} \mathrm{C}, 6.8 \%$ for A $30^{\circ} \mathrm{C}, 6.5 \%$ for $\mathrm{B} 22^{\circ} \mathrm{C}, 5.9 \%$ for $\mathrm{B}, 30^{\circ} \mathrm{C}$ ).

\section{Influence of the strain and the temperature on fluoranthene biotransformation}

The results of the multifactorial analysis are given in Table 2. The study of the interaction $\mathrm{S}^{*} \mathrm{~T} * \mathrm{t}$ (not significant, $\mathrm{p}=$ 0.71 ) indicated that the amount of FA transformed was always (independently of the strain and the time considered) lower at $22^{\circ} \mathrm{C}$ than at $30^{\circ} \mathrm{C}$ (temperature effect significant: $\mathrm{p}<0.0001)$. The differences between the amount transformed were more obvious between 24 and 72 hrs (Figure 4 and Table 2).

The strain effect was significant $(p=0.0007)$, but has to be related to the significant $S * t$ interaction $(p=0.002)$ shown in Figure 5. The graphic indicates that the mean amount of FA transformed was lower for strain A during the first 72 hrs $(3.29 \mathrm{mg} / \mathrm{g}$ of dry mycelium versus 3.72 at $24 \mathrm{hrs}, 3.83$ versus 4.06 at $48 \mathrm{hrs}, 4.01$ versus 4.19 at $72 \mathrm{hrs}$ ). The differences between the two strains decreased during this time and then an inversion was observed (4.46 versus 4.40 at $96 \mathrm{hrs}, 4.55$ versus 4.52 at $120 \mathrm{hrs}$ ). For $22^{\circ} \mathrm{C}$, the difference between the two strains was only significant at $24 \mathrm{hrs}$ (difference $\mathrm{A}-\mathrm{B}=0.44 \mathrm{mg} / \mathrm{g}$ of dry mycelium, $\mathrm{p}=$ 0.002 ), for $30^{\circ} \mathrm{C}$ at 24 and 48 hrs (differences $\mathrm{A}-\mathrm{B}=-0.41$ and $-0.33 \mathrm{mg} / \mathrm{g}$ of dry mycelium, $\mathrm{p}=0.003$ and 0.02 respectively with the Fisher PLSD test; only the difference observed at $24 \mathrm{hrs}$ was significant with the Tukey-Kramer test, $p=0.05$ ). In conclusion, the strain effect was significant only during the first $48 \mathrm{hrs}$ of the kinetics.

Influence of the time of incubation on fluoranthene biotransformation 


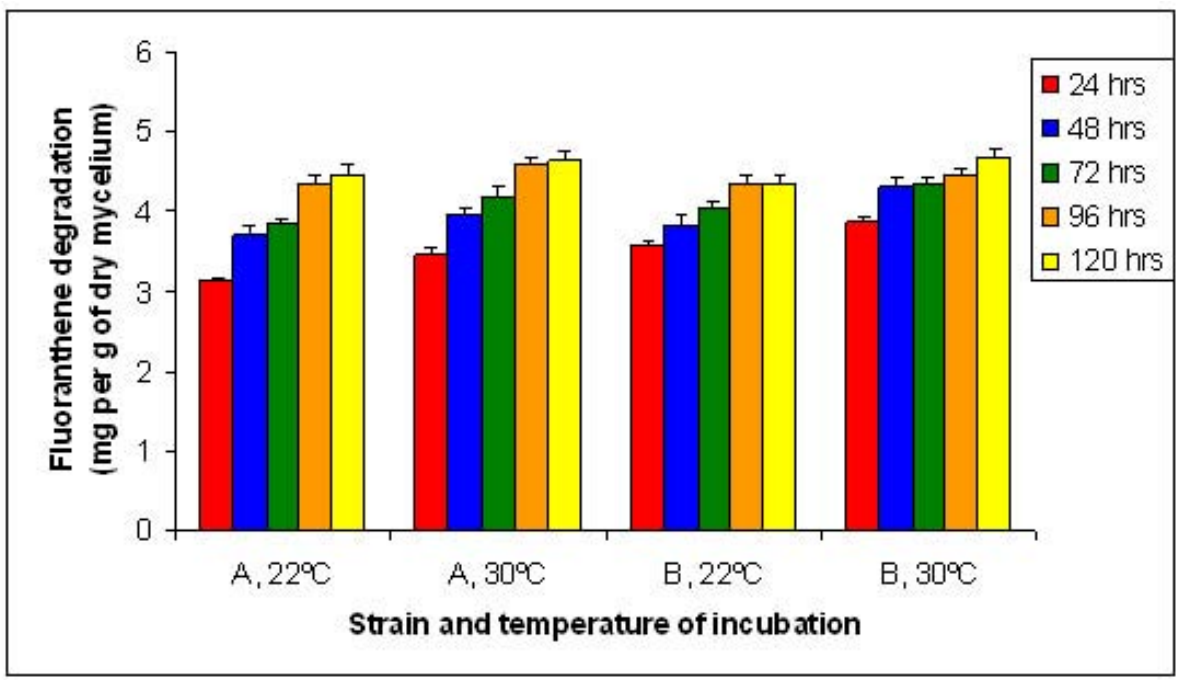

Figure 4. Strain*Temperature*time interaction for fluoranthene transformation by $A$. fusca strains $A$ and B (error bars: one standard error).

An analysis of the regression variance showed a positive and significant regression of the amount of FA transformed according to the time of incubation $(\mathrm{p}<0.0001$ for the four groups).

The four kinetics are represented in Figure 6. The slopes were $0.0138,0.0123,0.0086$ and $0.0074 \mathrm{mg} / \mathrm{g}$ of dry mycelium $/ \mathrm{h}$ respectively for the groups $\mathrm{A}, 22^{\circ} \mathrm{C} ; \mathrm{A}, 30^{\circ} \mathrm{C}$; $\mathrm{B}, 22^{\circ} \mathrm{C} ; \mathrm{A}, \mathrm{B}, 30^{\circ} \mathrm{C}$.

For strain A, the kinetics were parallel at $22^{\circ} \mathrm{C}$ and $30^{\circ} \mathrm{C}$ (difference between the slopes $=0.0014 \mathrm{mg} / \mathrm{g}$ dry mycelium $/ \mathrm{h}$ not significant, $\mathrm{p}=0.40$ ), the increase in the

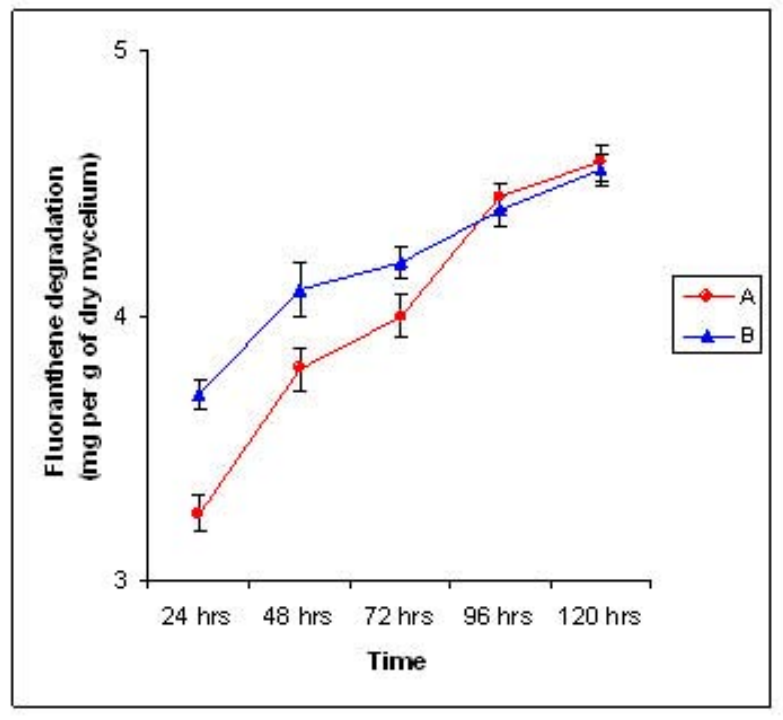

Figure 5. Strain*time interaction for fluoranthene transformation by $A$. fusca strains $A$ and $B$ (error bars: one standard error; temperature: $30^{\circ} \mathrm{C}$ ). mean amount of FA transformed being $0.31 \mathrm{mg} / \mathrm{g}$ of dry mycelium/d. The same observations were made for strain B (difference between the slopes $=0.0012 \mathrm{mg} / \mathrm{g}$ of dry mycelium $/ \mathrm{h}$ not significant, $\mathrm{p}=0.50$ ), the increase in the mean amount transformed being $0.19 \mathrm{mg} / \mathrm{g}$ of dry mycelium/d.

However the kinetics of FA transformation was significantly faster for strain A than for strain $\mathrm{B}$, the rate was increased by 1.6 time (difference between the slopes = $0.005 \mathrm{mg} / \mathrm{g}$ of dry mycelium $/ \mathrm{h}, \mathrm{p}=0.01$ ). These results were in agreement with those obtained with the multifactorial variance analysis and with the "a posteriori" tests.

\section{Comparison of the kinetics of anthracene and fluoranthene biotransformation}

For strain $\mathrm{A}$, the kinetics were faster for $\mathrm{AC}$ than for $\mathrm{FA}$ both at $22^{\circ} \mathrm{C}$ and at $30^{\circ} \mathrm{C}$, respectively 1.5 time at $22^{\circ} \mathrm{C}$ (difference between the slopes $=0.0075 \mathrm{mg} / \mathrm{gof}$ dry mycelium $/ \mathrm{h}$ significant, $\mathrm{p}=0.001$ ), and 1.6 time at $30^{\circ} \mathrm{C}$ (difference between the slopes $=0.0074 \mathrm{mg} / \mathrm{gof}$ dry mycelium $/ \mathrm{h}$ significant $\mathrm{p}=0.003$ ). This was also observed for strain $\mathrm{B}$ : the kinetics was 2.6 times faster at $22^{\circ} \mathrm{C}$ (difference between the slopes $=0.0135 \mathrm{mg} / \mathrm{g}$ of dry mycelium $/ \mathrm{h}$ significant $\mathrm{p}=0.0004)$ and 1.5 time at $30^{\circ} \mathrm{C}$ but the difference was not significant in this case.

\section{DISCUSSION}

The present study reveals the potential of the species $A$. fusca for the transformation / degradation of two PAHs: AC and FA, and the modification of its efficiency according to the habitat it was isolated from.

For both AC and FA bioremediation assays conducted with A. fusca: the differences in efficiency observed between the 
strains, the occurrence of new peaks on the HPLC profiles after $24 \mathrm{hrs}$ of incubation, the progressive decrease of these peaks between $24 \mathrm{hrs}$ and $120 \mathrm{hrs}$, together with the decrease of the peak corresponding to the xenobiotic, were an indication of the biodegradation activity of $A$. fusca. Identification of the metabolites produced was not undertaken in this work.

Concerning AC, the strain of A. fusca from the contaminated soil (strain A) was considerably more efficient than strain $\mathrm{B}$, since the mean amount of $\mathrm{AC}$ transformed was two times higher. The incubation at $30^{\circ} \mathrm{C}$ did not have any effect on AC transformation by strain A, while it had a significant inhibitory effect on strain B between 72 and $120 \mathrm{hrs}$. The transformation rate was similar for $\mathrm{A}, 22^{\circ} \mathrm{C}, \mathrm{A}, 30^{\circ} \mathrm{C}$ and $\mathrm{B}, 22^{\circ} \mathrm{C}$; and was lower for $\mathrm{B}, 30^{\circ} \mathrm{C}$.

Concerning FA, the mean amount transformed was slightly but significantly lower for strain A during the first 48 hrs. The transformation rate exhibited by strain $\mathrm{A}$ was higher than that observed for strain B. No differences in the transformation rates were obtained as a function of the temperature both for strain A and B.

On the whole, the transformation rate was higher for AC than for FA with both strains (1.5 to 2.6 times). The high levels of transformation observed after $24 \mathrm{hrs}$ was not a specific feature since it has been reported in the literature for numerous fungi and xenobiotics.
Previous work by Giraud et al. (2001) showed that FA was more easily degraded by fungi than $\mathrm{AC}$, in this work this was the case for strain B coming from a collection. Other studies showed similar results with the two molecules (Krivobok et al. 1998; Salicis et al. 1999) and this was here observed for strain A isolated from a contaminated soil. Most reports pointed out the high efficiency of the Zygomycete group for PAHs degradation, mostly Rhizopus arrhizus and the Cunninghamella genus (Cerniglia, 1993; Krivobok et al. 1998; Salicis et al. 1999), but also Absidia cylindrospora (Giraud et al. 2001). In this work we showed that $A$. fusca is also an interesting species with regard to its PAHs transformation / degradation capability.

Fungal biotransformation and/or degradation of environmental xenobiotics, and particularly PAHs, has been extensively studied in the Basidiomycete group and particularly the white-rot fungi (Pointing, 2001; Tekere et al. 2005). In this work we confirm that some Zygomycetes can also be very efficient. In two previous reports we showed that $A$. fusca can degrade efficiently a wide spectrum of xenobiotics: different classes of herbicides (mostly metribuzin and metobromuron), phenolic compounds (mostly ferulic acid), pentachlorophenol (Bordjiba et al. 2001; Guiraud et al. 2003). In both studies, the biodegradation capabilities were shown to be considerably increased in the strain isolated from a polluted milieu (strain A). Here we observed that $A$. fusca is also efficient in the degradation of PAHs such as AC and FA, with again an increased capability in strain $\mathrm{A}$ at least for

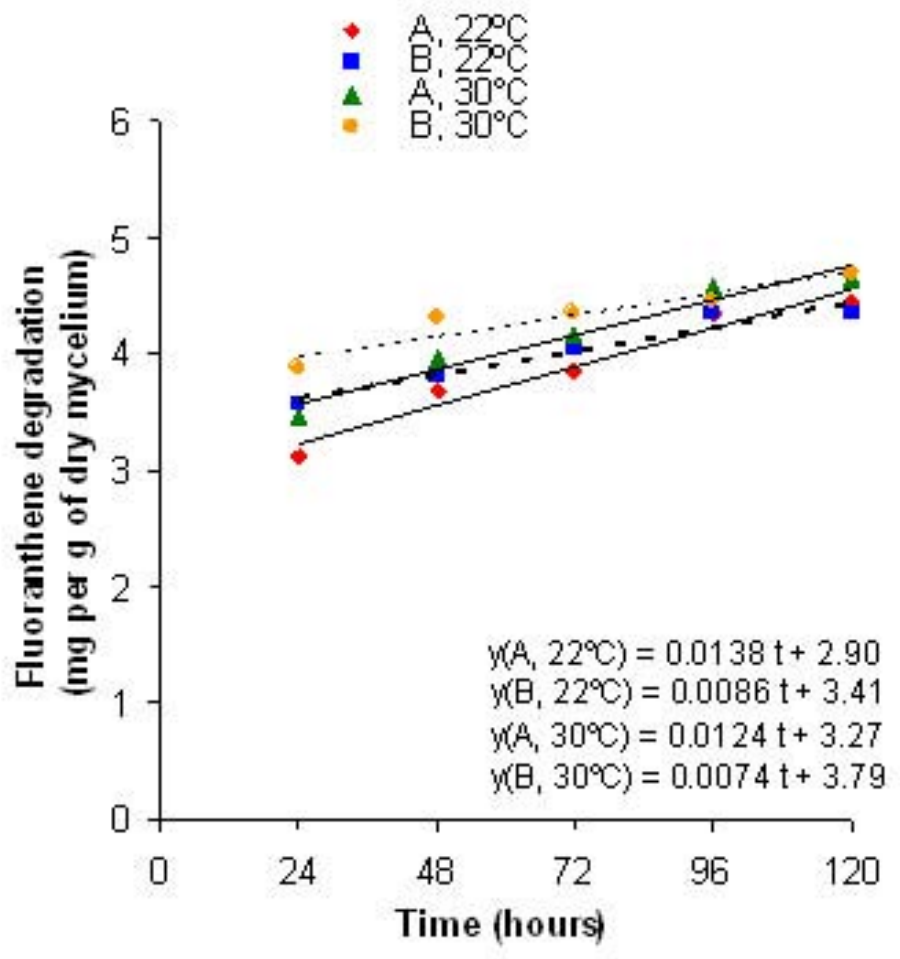

Figure 6. Kinetics of fluoranthene transformation by $A$. fusca strains $A$ and $B$ as a function of the temperature (mean values of the amount degraded). 
AC degradation. Moreover strain A was less sensitive to the temperature changes. The polluted environment has probably favoured the selection of a strain expressing low specific but efficient enzymatic systems able to degrade a large panel of molecules. This work underlines the interest of studying the microbial populations able to adapt in polluted ecosystems for bioremediation purpose.

\section{REFERENCES}

BOGAN, B.W. and LAMAR, R.T. Polycyclic aromatic hydrocarbon-degrading capabilities of Phanerochaete laevis HHB-1625 and its extracellular ligninolytic enzymes. Applied and Environmental Microbiology, May 1996, vol. 62 , no. 5 , p. $1597-1603$.

BONNET, J.L.; GUIRAUD, P.; DUSSER, M.; KADRI, M.; LAFFOSSE, J.; STEIMAN, R. and BOHATIER, J. Assessment of anthracene toxicity toward environmental eukaryotic microorganisms: Tetrahymena pyriformis and selected micromycetes. Ecotoxicology and Environmental Safety, January 2005, vol. 60, no. 1, p. 87-100.

BORDJIBA, Ouahiba; STEIMAN, Régine; KADRI, Malika; SEMADI, Ammar and GUIRAUD, Pascale. Removal of herbicides from liquid media by fungi isolated from a contaminated soil. Journal of Environmental Quality, March-April 2001, vol. 30, no. 2, p. 418-426.

CERNIGLIA, CARL E. Fungal metabolism of polycyclic aromatic hydrocarbons: past, present and future applications in bioremediation. Journal of Industrial Microbiology and Biotechnology, November 1997, vol. 19, no. 5-6, p. 324-333.

CERNIGLIA, Carl E. Biodegradation of polycyclic aromatic hydrocarbons. Current Opinion in Biotechnology, June 1993, vol. 4, no. 3, p. 331-338.

CHAUDHRY, G. Rasul. Biological degradation and bioremediation of toxic chemicals. Portland, Oregon, USA; Dioscorides Press, 1994. 528 p. ISBN 0-41-262290-4.

DEAN-ROSS, Deborah; MOODY, Joanna D.; FREEMAN, James P.; DOERGE, Daniel R. and CERNIGLIA, Carl E. Metabolism of anthracene by a Rhodococcus species. FEMS Microbiological Letters, October 2001, vol. 204, no. 1, p. 205-211.

GALZY, P. and SLONIMSKI, P. Variations physiologiques de la levure au cours de la croissance sur l'acide lactique comme seule source de carbone. Comptes Rendus de l'Académie des Sciences, December 1957, vol. 245 , no. 25 , p. $2423-2426$.

GIRAUD, F.; GUIRAUD, P.; KADRI, M.; BLAKE, G. and STEIMAN, R. Biodegradation of anthracene and fluoranthene by fungi isolated from an experimental constructed wetland for wastewater treatment. Water Research, December 2001, vol. 35, no. 17, p. 4126-4136.
GUIRAUD, P.; VILLEMAIN, D.; KADRI, M.; BORDJIBA, O. and STEIMAN, R. Biodegradation capability of Absidia fusca Linnemann towards environmental pollutants. Chemosphere, July 2003, vol. 52, no. 4 , p. 663-671.

HAMMEL, K.E. Mechanisms for polycyclic aromatic hydrocarbon degradation by lignolytic fungi. Environmental Health Perspectives, January 1995, vol. 103, suppl. 5, p. 41-43.

HARAYAMA, Shigeaki. Polycyclic aromatic hydrocarbon bioremediation design. Current Opinion in Biotechnology, June 1997, vol. 8, no. 3, p. 268-273.

KÄSTNER, M. and MAHRO, B. Microbial degradation of polycyclic aromatic hydrocarbons in soils affected by the organic matrix of compost. Applied Microbiology and Biotechnology, January 1996, vol. 44, no. 5, p. 668-675.

KELLEY, I.; FREEMAN, J.P.; EVANS, F.E. and CERNIGLIA, C.E. Identification of metabolites from the degradation of fluoranthene by Mycobacterium sp. Strain PYR-1. Applied and Environmental Microbiology, 1993, vol. 59 , no. 3 , p. $800-806$.

KRIVOBOK, S.; MIRIOUCHKINE, E.; SEIGLEMURANDI, F. and BENOIT-GUYOD, J.L. Biodegradation of anthracene by soil fungi. Chemosphere, August 1998, vol. 37 , no. 3, p. 523-530.

MAHMOOD, S.K. and RAMA RAO, P. Microbial abundance and degradation of polycyclic aromatic hydrocarbons in soil. Bulletin of Environmental Contamination and Toxicology, April 1993, vol. 50, no. 4, p. 486-491.

MENZIE, Charles A.; POTOCKI, Bonnie B. and SANTODONATO, Joseph. Exposure to carcinogenic PAHs in the environment. Environmental Science and Technology, July 1992, vol. 26, no. 7, p. 1278-1284.

MOODY, Joanna D.; FREEMAN, James P.; DOERGE, Daniel R. and CERNIGLIA, Carl E. Degradation of phenanthrene and anthracene by cell suspensions of Mycobacterium sp. strain PYR-1. Applied and Environmental Microbiology, April 2001, vol. 67, no. 4, p. 1476-1483.

MÜNCNEROVA, D. and AUGUSTIN, J. Fungal metabolism and detoxification of polycyclic aromatic hydrocarbons: a review. Bioresource Technology, 1994, vol. 48, no. 2, p. 97-106.

NADON, L.; SIEMIATYCKI, J.; DEWAR, R.; KREWSKI, D. and GUERIN, M. Cancer risk due to occupational exposure to polycyclic aromatic hydrocarbons. American Journal of Industrial Medicine, 1995, vol. 28, no. 3, p. 303-324. 
PASZCZYNSKI, Andrzej and CRAWFORD, Ronald L. Potential for bioremediation of xenobiotic compounds by the white-rot fungus Phanerochaete chrysosporium. Biotechnology Progress, July 1995, vol. 11, no. 4, p. 368379.

POINTING, S.B. Feasibility of bioremediation by white-rot fungi. Applied Microbiology and Biotechnology, October 2001 , vol. 57 , no. $1-2$, p. $20-33$.

RAVELET, C.; KRIVOBOK, S., SAGE, L. and STEIMAN, R. Biodegradation of pyrene by sediment fungi. Chemosphere, March 2000, vol. 40, no. 5, p. 557-563.

SALICIS, F.; KRIVOBOK, S.; JACK, M. and BENOITGUYOD, J.L. Biodegradation of fluoranthene by soil fungi. Chemosphere, June 1999, vol. 38, no. 13, p. 3031-3039.

TEKERE, M.; READ, J.S. and MATTIASSON, B. Polycyclic aromatic hydrocarbon biodegradation in extracellular fluids and static batch cultures of selected subtropical white-rot fungi. Journal of Biotechnology, February 2005, vol. 115, no. 4, p. 367-377. 